\title{
Selüloz Nanofibril İçeren Emülsiyon Şablonlu Gözenekli Polimer Kompozitlerin Hazırlanması ve Gizli Isıl Enerji Depolama Uygulamaları
}

\section{Preparation of Emulsion Templated Porous Polymer Composites Containing Cellulose Nanofibril and Latent Thermal Energy Storage Applications}

\author{
Zehra Türkoğlu ${ }^{1}$, Hatice Hande Mert ${ }^{2 *}$, Emine Hilal Mert ${ }^{3}$, Mehmet Selçuk Mert ${ }^{4}$ \\ Geliş / Received: 15/07/2021 \\ Revize / Revised: 24/08/2021 \\ Kabul / Accepted: 26/08/2021
}

\begin{abstract}
ÖZ
Bu çalışmada, düşük sıcaklık gizli ısıl enerji depolama uygulamalarında destek malzeme olarak kullanılabilecek gözenekli polimer kompozitler emülsiyon kalıplama yöntemiyle üretilmiş ve elde edilen malzemelerin morfolojik, 1sıl ve mekanik özellikleri araştırılmıştır. Bu amaçla fibril formundaki nanoselüloz modifiye edilerek emülsiyon sistemiyle uyumlu hale getirilmiş ve yüksek iç fazlı emülsiyonların polimerizasyonuyla elde edilen gözenekli polimerik köpüklerin özelliklerinin geliştirilmesi amacıyla dolgu olarak kullanılmıştır. Elde edilen gözenekli malzemelerin Taramalı elektron mikroskobu (SEM), termogravimetrik analiz (TGA) ve basma modülü ölçümleriyle sırasıyla morfolojik, ısıl ve mekanik özellikleri araştırılmıştır. Ayrıca üretilen destek malzemelerinin spesifik yüzey alanı değerleri Brunauer-Emmet-Teller (BET) yüzey alanı ve gözenek boyutu analiz cihazı ile belirlenmiş̧ir. Gözenekli malzemelerdeki selüloz nanofibril dolgu katkısının kompozit malzemelerin gözenek morfolojisine ve ısıl kararlılıklarına olumlu katkı sağladığı, yüzey alanı değerlerini ise arttırdığı görülmüştür. Elde edilen kompozit malzemeler n-pentadekan içeren yapıca kararlı kompozit faz değiştiren maddelerin (FDM'lerin) üretiminde destek materyali olarak kullanılmıştır. Diferansiyel Taramalı Kalorimetre (DSC) ile gerçekleştirilen 1sıl analizler sonucunda ağırlıkça \%0,75 selüloz nanofibril dolgu içeren matrise sahip kompozit FDM'nin en yüksek n-pentadekan kapsülasyon oranına $(\% 61,12)$ ve en yüksek $1 s ı l$ enerji depolama kapasitesine $(122,0 \mathrm{~J} / \mathrm{g})$ sahip olduğu bulunmuştur.
\end{abstract}

Anahtar Kelimeler- Emülsiyon, Selüloz, Kompozit Malzeme, Faz Değiştiren Maddeler, Isıl Enerji Depolama

\begin{abstract}
In this study, porous polymer composites that can be used as support materials in low temperature latent thermal energy storage applications were produced by emulsion templating method and the morphological, thermal and mechanical properties of the obtained materials were investigated. For this purpose, nanocellulose in the form of fibril was modified in order to make compatible with the emulsion system and used as a filler to improve the
\end{abstract}

1İletişim: zkanli3@gmail.com (https://orcid.org/ 0000-0002-3731-7883)

Kimya Mühendisliği Bölümü, Yalova Üniversitesi, Mühendislik Fakültesi, 77200, Yalova, Türkiye

2*Sorumlu yazar iletişim: hndmert@yalova.edu.tr (https://orcid.org/ 0000-0003-0743-1981)

Kimya Mühendisliği Bölümü, Yalova Üniversitesi, Mühendislik Fakültesi, 77200, Yalova, Türkiye

3İletişim: hmert@yalova.edu.tr (https://orcid.org/ 0000-0003-4267-7469)

Polimer Malzeme Mühendisliği Bölümü, Yalova Üniversitesi, Mühendislik Fakültesi, 77200, Yalova, Türkiye

4İletişim: msmert@yalova.edu.tr (https://orcid.org/0000-0002-8646-0133)

Enerji Sistemleri Mühendisliği Bölümü, Yalova Üniversitesi, Mühendislik Fakültesi, 77200, Yalova, Türkiye 
properties of porous polymeric foams obtained by polymerization of high internal phase emulsions. The morphological, thermal and mechanical properties of the obtained porous materials were investigated by Scanning Electron Microscopy (SEM), thermogravimetric analysis (TGA) and compression modulus measurements, respectively. In addition, the specific surface area values of the produced support materials were determined with the Brunauer-Emmet-Teller (BET) surface area and pore size analyzer. It has been observed that the addition of cellulose nanofibril filler in porous materials contributes positively to the pore morphology and thermal stability of the composite materials, while increasing the surface area values. The obtained composite materials were used as support materials in the production of shape-stabilized composite phase change materials (PCMs) containing npentadecane. As a result of thermal analyzes performed with Differential Scanning Calorimetry (DSC); it was found that composite PCM with a support matrix containing $0.75 \mathrm{wt}(\%)$ cellulose nanofibril filler has the highest $\mathrm{n}$-pentadecane encapsulation ratio $(61.12 \%)$ and the highest thermal energy storage capacity $(122.0 \mathrm{~J} / \mathrm{g})$.

Keywords- Emulsion, Cellulose, Composite Material, Phase Change Materials, Thermal Energy Storage

\section{I.GíRiş}

Sanayileşme ve hızlı nüfus artışına paralel olarak enerji kullanımındaki artış, fosil yakıt kullanımının yarattığı çevresel sorunlar, sera gazı seviyesinde görülen ciddi yükselişler bilim insanlarını alternatif yeni ve sürdürülebilir enerji kaynaklarının bulunmasına yöneltmiştir. Yeni enerji depolama teknolojilerinin geliştirilmesi, yenilenebilir enerji kaynaklarından yararlanarak kaynakların etkin kullanımı ve çevresel zararların en aza indirilmesi açısından önem arz etmektedir. Bu bağlamda ısıl enerji depolama yöntemlerinden biri olan ve faz değiştiren maddeler (FDM'ler) yoluyla büyük miktarda gizli ısının depolanmasına imkan veren gizli 1sı depolama yöntemi son yıllarda ilgi çekmektedir [1,2]. FDM'ler yoluyla 1sıl enerjinin depolanması neredeyse sabit bir sıcaklıkta gizli ısının absorlanması ve salınması yoluyla gerçekleşir [3-5]. FDM'ler binaların 1sıl konforun sağlanmasında, 1Sı ayarlamalı tekstil ürünlerinde, gıda ürünlerinin/organların taşınmasında, elektronik cihazlarda, güneş enerjisi sistemlerinde, iç mekan 1sıtma/soğutma sistemlerinde tercih edilmektedir [6]. Organik FDM sınıfından olan parafinler, uygun ısıl ve kimyasal özellikleri, yüksek enerji depolama kapasiteleri, düşük maliyetleri gibi özellikleriyle öne çıkmaktadır [7]. Ancak ısıl yönetimin gerçekleştiği birçok uygulamada, faz değişimi esnasında eriyen FDM'nin sızmasını önlemek amacıyla kapsülasyona ihtiyaç duyulmaktadır. Yapıca kararlı FDM'ler, belirli bir yapı içerisinde FDM'nin hapsedilmesi suretiyle erime sıcaklığının üzerinde sızıntının önlenmesi ilkesine dayanmaktadır [8]. Yapıca kararlılığın sağlanmasında uygun destek malzemesinin ve hazırlama yönteminin seçimi uygulamadaki başarı açısından büyük rol oynamaktadır. Mikrokapsülasyon, nano malzemeler, polimer matrisler, gözenekli malzemeler (gözenekli karbon, grafit, silika, killer vb.) yoluyla FDM'lerin yapıca kararlılığı sağlanabilmektedir [9]. Gözenekli malzemeler kapiler, yüzey gerilimi, hidrojen bağı, Van der Waals kuvveti vb. gibi kuvvetlere sahiptir ve FDM sızıntısı önlemek için etkili kılcal ve adsorpsiyon özellikleri sağlamaktadır.

Yüksek iç fazlı emülsiyonların polimerizasyonu yoluyla sentezlenen ve poliHIPE olarak adlandırılan emülsiyon şablonlu gözenekli polimerler doku mühendisliği, kromotografi, katalizör uygulamaları, adsorpsiyon/filtrasyon prosesleri gibi pek çok alanda kullanılmaktadır [10]. Son yıllarda yapılan çalışmalarda bu malzemelerin ısıl enerji depolama uygulamalarında destek materyali olarak da tercih edildiği görülmektedir [1114]. Bu malzemeler, düşük yoğunlukları, kontrol edilebilir yüzey alanları ve gözenek boyutu dağılımları sayesinde üstün absorplama özellikleri gösteren mükemmel destek matrisleridir. Emülsiyon sistemine çeşitli dolgularla yapılan katkılandırma sonucu elde edilen poliHIPE kompozitlerin 1sıl, morfolojik, mekanik özellikleri iyileştirilebilmektedir $[15,16]$.

Selüloz nanofibril, yenilenebilir kaynaklardan elde edilen, çevre dostu, yüksek mukavemetli ve süper emicilik özelliklerine sahip bir malzemedir [17,18]. Selüloz hamurunun fibril haline getirilmesiyle elde edilen ve amfifilik karakter sergileyen bu malzemeler, kompozit malzemelerin geliştirilmesi amacıyla dolgu malzemesi olarak kullanılabilmektedir. Ayrıca yapısında yoğun olarak hidroksil grupları içermesi nedeniyle uygulama alanına bağlı olarak uyumlaştırma amacıyla farklı modifikasyonları gerçekleştirilebilmektedir [19,20].

Literatürde FDM mikrokapsüllerin elde edilmesine yönelik çalışmalarda, selüloz esaslı malzemelerin, Pickering emülsiyon sistemlerinde stabilizatör olarak kullanıldığı çalışmalara rastlanmaktadır. Li vd. [21], RT25HC parafinini içeren bir çekirdek ve selüloz nanofibril kabuktan oluşan FDM kompoziti Pickering emülsiyon yöntemiyle üretmişler ve elde ettikleri kapsüllerin 1sıl özelliklerini incelemişlerdir. Zhang vd. [22], FDM olarak seçtikleri parafin ve n-oktadekanı, melamin formaldehit bir kabukla kapsüle etmişler, selüloz nanokristalleri ise sentez esnasında Pickering emülsiyon stabilizatörü olarak kullanmışlardır. Bir başka çalışmada Shen vd. [23], 


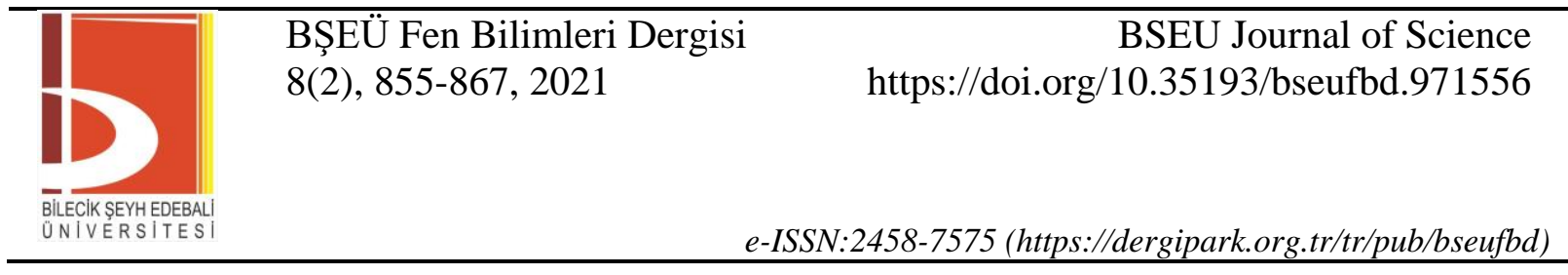

selüloz nanofibril/gümüş nanopartikül kompozitleri hazırlamış ve FDM olarak seçtikleri sodyum asetat trihidratın performansını iyileştirmek için destek olarak kullanmışlardır. Kanlı vd. [24], dondurarak kurutma yöntemiyle elde ettikleri gözenekli yapıdaki selüloz nanofibril köpüğü, FDM olarak n-hekzadekan içeren yapıca kararlı FDM üretiminde destek materyali olarak kullanmışlardır.

$\mathrm{Bu}$ çalı̧̧mada litaratürden farklı olarak ilk defa selüloz nanofibriller modifiye edilerek, gözenekli poliHIPE kompozitlerin hazırlanmasında dolgu olarak kullanılmıştır. Farklı oranlarda dolgular içeren kompozitlerin morfolojik, ısıl ve mekanik özellikleri belirlenmiş ve bu kompozit malzemeler 15 karbonlu parafin türünde bir FDM olan n-pentadekanın (PD) yapıca kararlı hale getirilmesinde destek materyali olarak kullanılmışıır. Soğutma uygulamalarında kullanım amacıyla üretilen yapıca kararlı kompozit FDMlerin isıl özelikleri belirlenmiş ve kapsülasyon oranları hesaplanmıştır.

\section{MALZEMELER VE METOTLAR}

\section{A. Kullanulan Malzemeler}

Stiren, n-pentadekan, potasyum persülfat kimyasalları Merck (Almanya) firmasından, divinil benzen, setil trimetil amonyum bromür, Span $80, \mathrm{CaCl}_{2} \cdot 6 \mathrm{H}_{2} \mathrm{O}$,Sigma-Aldrich (Almanya) firmasından, selüloz nanofibril Nanografi (Türkiye) firmasından satın alınmıştır. Deneysel çalışmanın bütün aşamalarında ultra saf su kullanılmıştır. Üretim aşamaları Şekil 1'de şematik olarak gösterilmiş̧ir.

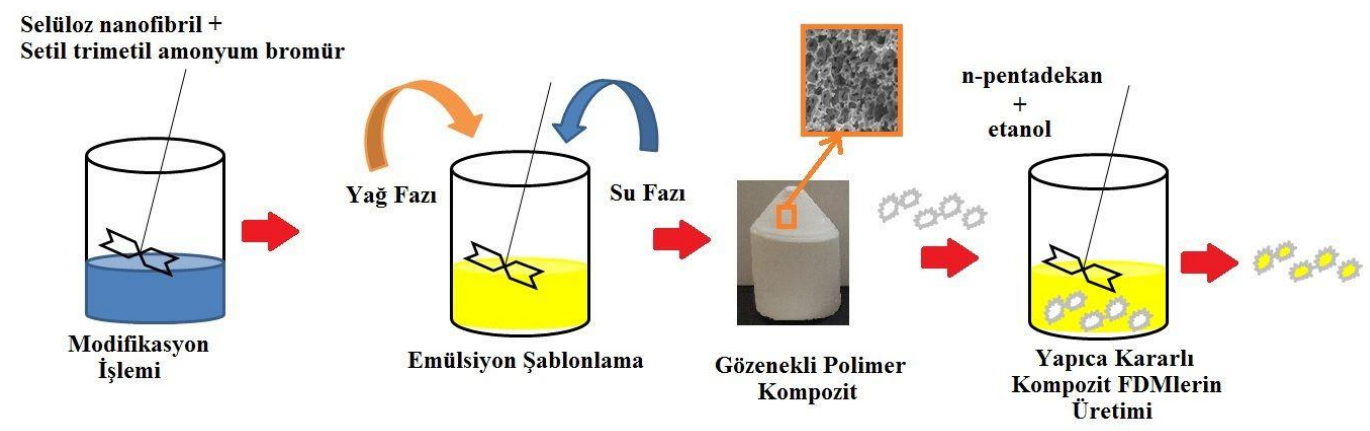

Şekil 1. N-pentadekan içeren yapıca kararlı kompozit FDMlerin üretim adımları

\section{B. Modifiye Edilmiş Selüloz Nanofibrillerin Eldesi ve Karakterizasyonu}

Selüloz nanofibrilin modifikasyon işlemi önceki çalışmamızdaki [24] prosedüre göre gerçekleştirilmiştir. Selüloz nanofibrillerin yüksek iç fazlı emülsiyon sistemiyle uyumlu hale getirilmesi amacıyla setil trimetil amonyum bromür kimyasalı ile modifikasyon işlemi gerçekleştirilmiştir. Bu amaçla selüloz nanofibriller $100 \mathrm{ml}$ su içinde $55^{\circ} \mathrm{C}$ 'de karıştırılmış ve bir ultrasonikatör yardımıyla homojenize edilmiştir. Elde edilen çözelti üzerine ağırlıkça $\% 2$ oranında setil trimetil amonyum bromür içeren çözelti eklenerek $55{ }^{\circ} \mathrm{C}$ 'de karıştırma işlemi gerçekleştirilmiştir. Elde edilen çözelti derin dondurucuda dondurulmasının ardından liyofilizatörde kurutulmuştur. Kurutma sonucunda elde edilen beyaz renkteki monolit toz haline getirilmiş ve gözenekli polimer kompozitlerin hazırlanmasında takviye edici olarak kullanılmıştır. Elde edilen modifiye dolguların kimyasal karakterizasyonu Fourier Dönüşümlü Kızıl ötesi spektrofotometresi (FT-IR Perkin Elmer, Spectrum 100) ile, morfolojik analizleri ise taramalı elektron mikroskobu (SEM) cihazı (FEI, Ouanta FEG 250 model) ile gerçekleştirilmiş̧ir.

\section{Emülsiyon Şablonlama Yöntemiyle Gözenekli Polimer Kompozitlerin Hazırlanması ve Karakterizasyonu}

Gözenekli polimer kompozitler, modifiye edilmiş selüloz nanofibril dolgular varlığında yüksek iç fazlı emülsiyonların şablonlanması yöntemiyle hazırlanmışıır. Yağ fazını oluşturan stiren (hacimce \%90), divinil benzen (hacimce \%10), Span 80 ve ağırlıkça değişen yüzdelerdeki dolgular $(\% 0,25$ - \%1,00) bir cam reaktöre konulmuş ve yarım saat süreyle oda sıcaklığında mekaniksel olarak karıştıılmıştır. Ardından bir ultrasonikatör yardımıyla karışım homojenize edilmiştir. KPS $(0,1 \mathrm{~g}), \mathrm{CaCl}_{2} \cdot 6 \mathrm{H}_{2} \mathrm{O}(\% 1)$ ve ultra saf sudan oluşan su fazı, yağ fazına damlalar halinde ilave edilmiş ve yarım saat süreyle karıştırma işlemine devam edilmiştir. Elde edilen 


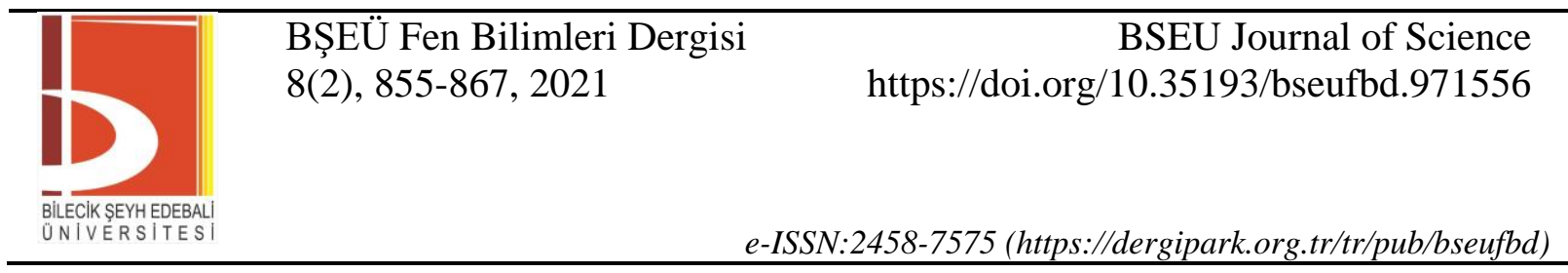

yüksek iç fazlı emülsiyon $60^{\circ} \mathrm{C}$ 'ye ayarlanmış bir etüvde 24 saat süreyle polimerleştirilmiştir. Elde edilen monolit formundaki numuneler 24 saat süreyle etanolle ekstrakte edilmiş ve süre sonunda vakum etüvünde kurutulmuştur. Polimer matrise katkılan modifiye dolguların 1sıl, morfolojik ve mekanik etkilerinin belirlenmesi amacıyla aynı prosedür selüloz nanofibril dolgular yokluğunda tekrar edilmiş̧ir. Elde edilen destek malzemeleri içerdikleri dolgu miktarına göre PHPF 0, PHPF 0.25, PHPF 0.50, PHPF 0.75 ve PHPF 1.00 olarak adlandırılmıştır.

Elde edilen gözenekli polimerlerin morfolojik, 1sıl ve mekanik özellikleri sırasıyla Taramalı Elektron Mikroskobu (SEM) (FEI, Ouanta FEG 250 model), termal analiz cihazı (Seiko TG/DTA 6300) ve çekme/basma deneyi cihazı (Zwick/Roell, 1.000 ve $20.000 \mathrm{~N}$, Almanya) ile belirlenmiştir. Spesifik yüzey alanı ölçümleri ise Micromeritics Gemini VII 2390t Tam Otomatik BET Yüzey Alanı ve Gözenek Boyutu Analiz Cihazı ile gerçekleştirilmiştir.

\section{D. n-Pentadekan İçeren Yapıca Kararlı Kompozit FDMlerin Üretilmesi ve Karakterizasyonu}

Üretilen gözenekli polimer kompozitler iskelet olarak kullanılarak, n-pentadekan $\left(\mathrm{C}_{15} \mathrm{H}_{32}\right)$ içeren yapıca kararlı kompozit FDMlerin impregnasyon işlemiyle üretilmiş̧ir. Bu amaçla, belirli miktardaki n-pentadekan etanol ile oda sıcaklığında bir manyetik karıştıııı yardımıyla karıştırılmış ve toz haline getirilen polimer kompozitlerin üzerine dökülmüştür. Karışım mekaniksel olarak oda sıcaklığında 24 saat süreyle karıştırılmıştır. Vakum etüvünde gerçekleşen kurutma işlemi sonrasında toz halinde yapıca kararlı kompozit FDMler elde edilmiştir. Elde edilen malzemelerin ısıl özellikleri diferansiyel taramalı kalorimetre (Seiko, DSC 7020) cihazı ile azot atmosferi altında belirlenmiştir. Kompozit FDMlerin n-pentadekan içerikleri Denklem (1)'e göre hesaplanmıştır [13]. Burada

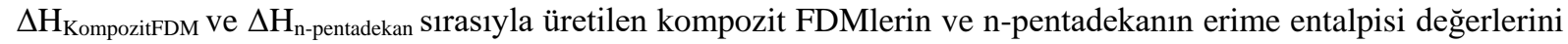
$\mathrm{J} / \mathrm{g}$ cinsinden göstermektedir.

$$
\text { n-pentadekan içeriği (\% ağır. })=\left[\Delta \mathrm{H}_{\text {Kompozit FDM }} / \Delta \mathrm{H}_{\text {n-pentadekan }}\right] \times 100
$$

\section{BULGULAR VE TARTIŞMA}

Yüksek iç fazlı emülsiyonlardan gözenekli polimer kompozitlerin elde edilmesinde emülsiyon kararlılığı önemli bir faktördür. Yüksek iç fazlı emülsiyonların hazırlanması esnasında organik esaslı yağ fazına katkılanan ve yüksek oranda hidroksil grupları içeren selüloz nanofibrillerin diğer kimyasallarla uyumlu hale getirmek için setil trimetil amonyum bromür ile modifikasyonları gerçekleştirilmiştir. Selüloz nanofibrillerin modifikasyon işlemi öncesi ve sonrası SEM görüntüleri sırasıyla Şekil $2 \mathrm{a}$ ve $2 \mathrm{~b}$ 'de sunulmuştur. Ticari olarak satın alınan selüloz nanofibrillerin ipliksi yapısı gerçekleştirilen modifikasyon işleminden sonra birbiriyle bağlantılı tabakalardan oluşan üç boyutlu bir yapıya dönüşmüştür.
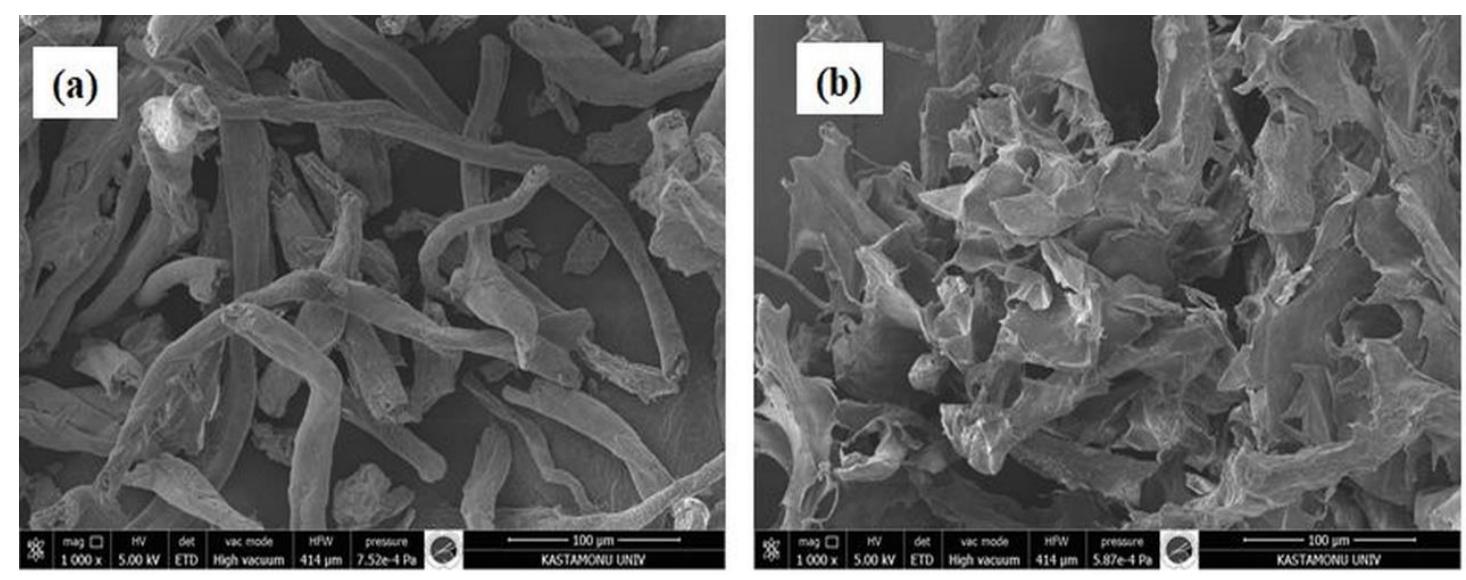

Şekil 2. Selüloz nanofibrillerin modifikasyon öncesi (a) ve sonrası (b) SEM görüntüleri (100 $\mu \mathrm{m})$

Modifiye edilen selüloz nanofibrillerin kimyasal yapısı FT-IR analiziyle aydınlatılmıştır. Şekil 3 'te modifikasyon öncesi ve sonrasında elde edilen selüloz nanofibrillere ait spektrumlar görülmektedir. Saf selüloz nanofibrile ait spektrum incelendiğinde $1324 \mathrm{~cm}^{-1}$ ' de görülen pik $\mathrm{O}-\mathrm{H}$ grubuna ait gerilme titreşimine aitken, 1055 $\mathrm{cm}^{-1}$ civarında ortaya çıkan pikler C-O bağlarına ait gerilme titreşimlerini göstermektedir [24]. $3336 \mathrm{~cm}^{-1}$ de görülen geniş pik selüloz moleküllerindeki hidroksil gruplarına ait O-H gerilme titreşimini göstermektedir. 2909 $\mathrm{cm}^{-1}$ görülen band ise selülozun alifatik bağlarındaki alkil gruplarını C-H gerilme titreşimine karşıllık gelir [25]. 
1600-1500 $\mathrm{cm}^{-1}$ aralığında bulunan absorpsiyon bandı ise ligninin $\mathrm{C}=\mathrm{C}$ aromatik iskelet titreşimlerine karşılık gelmektedir. Modifiye edilmiş selüloz nanofibrillere ait pik incelendiğinde $2920-2850 \mathrm{~cm}^{-1}$ aralığında gözlenen pikler setil trimetil amonyum bromürdeki metil grupları kaynaklı $\mathrm{C}-\mathrm{H}$ gerilme titreşimlerinden ileri gelmektedir. Ayrıca bu moleküle ait C-H bükülme titreşimleri ise $1460 \mathrm{~cm}^{-1}$ civarında ortaya çıkmıştır. Bu molekülün amonyum grubu ile selüloz nanofibrillerin hidroksil gruplarının etkileşimi $3338 \mathrm{~cm}^{-1}$ bandında görülmektedir. Bu analiz sonuçlarına göre selüloz nanofibrillerin modifikasyon işleminin gerçekleştiği teyit edilmiştir.

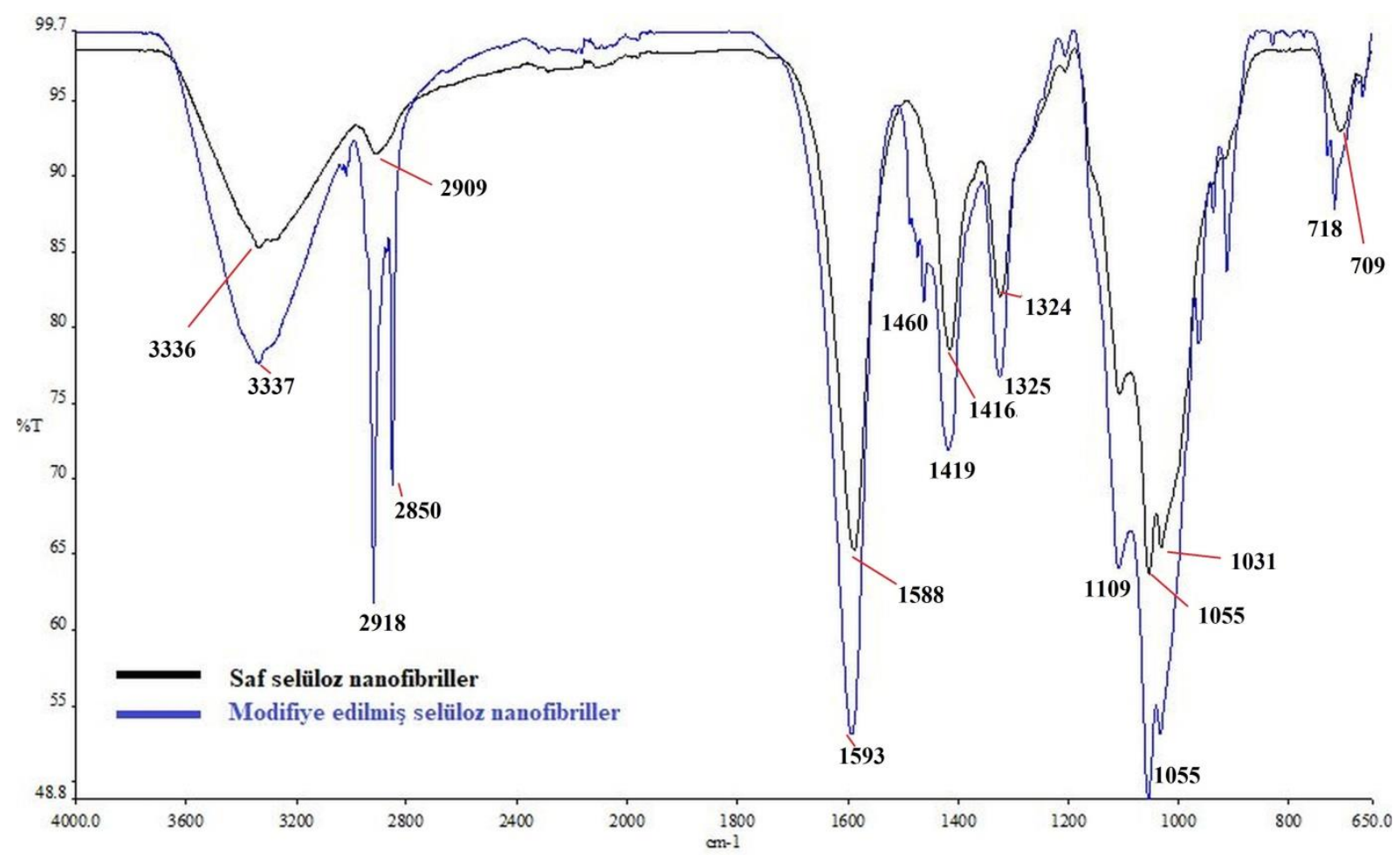

Şekil 3. Selüloz nanofibrillerin modifikasyon öncesi ve sonrası FT-IR spektrumları

Değişen oranlarda modifiye edilmiş selüloz nanofibrilleri içeren gözenekli polimer kompozitlerin morfolojik, 1sıl ve mekanik karakterizasyonları gerçekleştirilmiştir. Şekil 4'te elde edilen polimerik destek malzemelerin SEM görüntüleri yer almaktadır. Şekil 4'ten görüldüğü üzere \%0,25 ila \%1,00 oranında katkılanan tüm polimer kompozitlerde açık gözeneklerin ve bu gözenekleri birbirine bağlayan geçitlerinin oluştuğu görülmektedir. Ayrıca, artan dolgu miktarının açık hücreli poliHIPE morfolojisine olumlu katkı sağladığı, buna karşın selüloz nanofibril içermeyen, katkısız poliHIPE malzemede gözenekli iskelet yapının oluşmadığı ve birbiri üzerine çökmüş tabakalı bir morfolojinin meydana geldiği görülmüştür. Bu sonuç, literatürle uyumlu olarak [17,21] selüloz nanofibril partiküllerin emülsiyon sisteminde yağ/su ara yüzeyinde yăg damlacıklarının birleşmesini ve de stabilizasyonu engelleyen stabilizatör benzeri bir görev üstlenmesinden kaynaklanmıştır. 


\begin{tabular}{|c|c|c|}
\hline & $\begin{array}{l}\text { BŞEÜ Fen Bilimleri Dergisi } \\
8(2), 855-867,2021\end{array}$ & $\begin{array}{r}\text { BSEU Journal of Science } \\
\text { https://doi.org/10.35193/bseufbd } 971556\end{array}$ \\
\hline $\begin{array}{l}\text { BiLECIKSEYHEDE } \\
\text { ONIVERSIT }\end{array}$ & & $2458-7575$ (https://dergipark.org.tr/tr/pub/bseufbd) \\
\hline
\end{tabular}
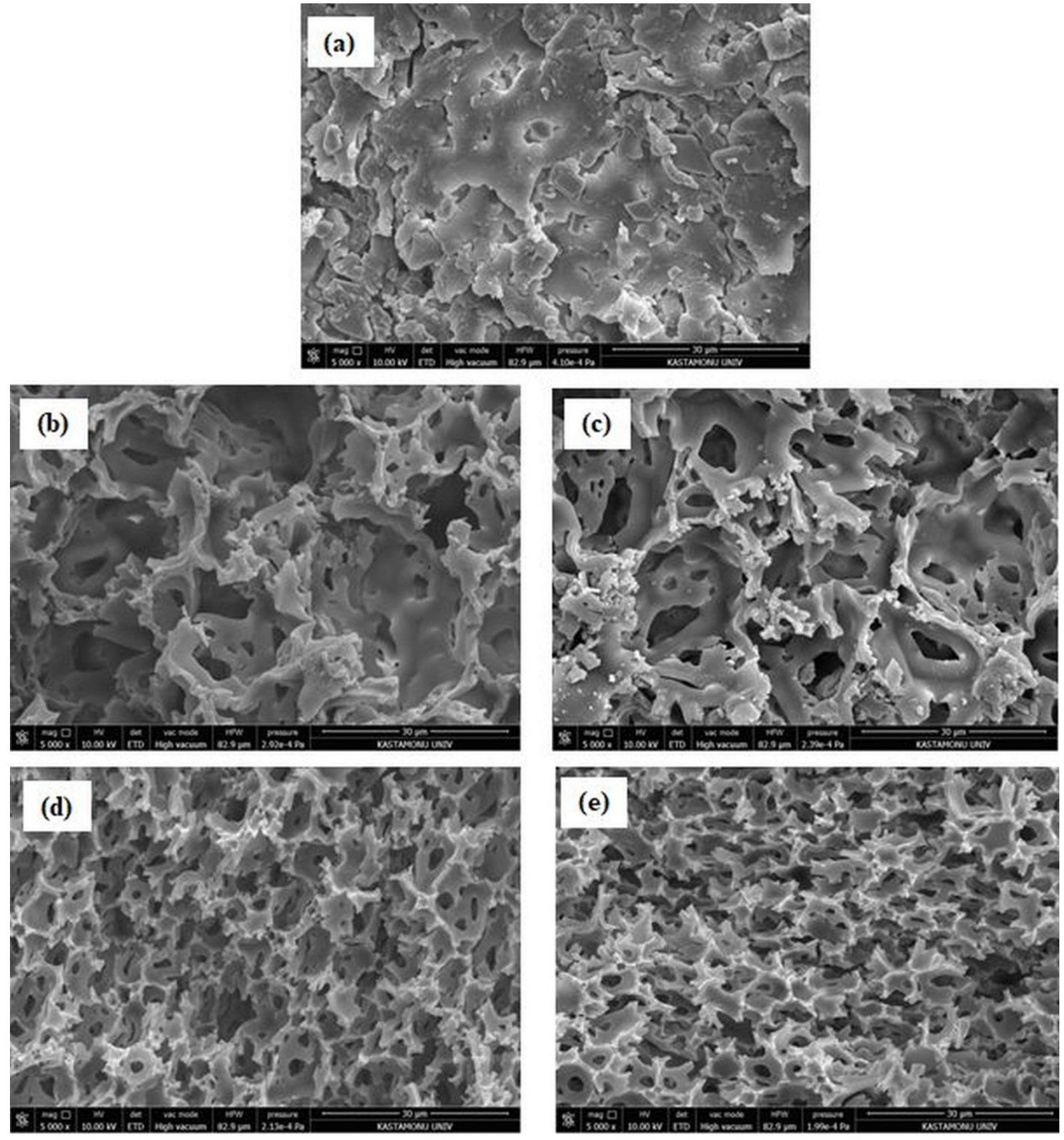

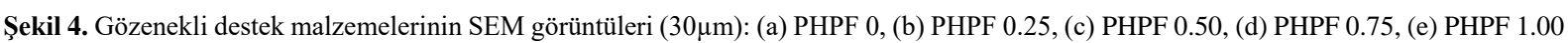

Üretilen gözenekli polimer malzemelerin spesifik yüzey alanı ölçümleri BET analizi ile gerçekleștirilmiş ve elde edilen sonuçlar Tablo 1'de sunulmuştur. Tablo 1'den görüldüğü üzere artan dolgu miktarına paralel olarak malzemelerin spesifik yüzey alanı değerlerinde de artış görülmüştür. Tüm malzemeler aynı emülsiyon formülasyonu kullanılarak üretildiğinden ve referans numune ile kompozit yapılı numuneler arasındaki tek fark farklı oranlardaki nanofibril katkılaması olduğundan bu durum kompozit elde etmek amacıyla artan oranlarda kullanılan selüloz nanofibrillerin yüzey alanının toplam yüzey alanına olan katkısı ile açıklanabilir. Yüzey alanında görülen bu artış FDM olarak seçilen ve bu destek malzemelerine entegre edilecek n-pentadekanın polimerik matrisdeki gözeneklere penetrasyonunu kolaylaştırması açısından istenen bir durumdur. 
Tablo 1. Gözenekli polimer malzemelerin spesifik yüzey alanı değerleri

\begin{tabular}{cc}
\hline Malzemeler & $\begin{array}{c}\text { Spesifik yüzey alanı değeri } \\
\boldsymbol{\delta}_{\text {BET }}\left(\mathbf{m}^{2} / \mathbf{g}\right)\end{array}$ \\
\hline PHPF 0 & 1,8851 \\
PHPF 0.25 & 2,0991 \\
PHPF 0.50 & 2,4687 \\
PHPF 0.75 & 2,9197 \\
PHPF 1.00 & 3,7617 \\
\hline
\end{tabular}

Farklı katkı oranlarında selüloz nanofibril partiküller içeren polimerik destek malzemelerinin 1sıl özellikleri termogravimetrik analiz (TGA) ile belirlenmiş, elde edilen termogramlar Şekil 5'te sunulmuştur. Ayrıca, TGA termogramlarından elde edilen ve gözenekli polimerlerin ağırlığının \%5'ini, \%10'unu, \%50'sini kaybettiği sıcaklık değerleri (sırasıyla $\mathrm{Td}_{5}, \mathrm{Td}_{10}$ ve $\mathrm{Td}_{50}$ ) bozunma hızları ile birlikte Tablo 2'de verilmiştir. Şekil 5 ve Tablo 2'den görüldüğü üzere selüloz nanofibril dolguları içeren tüm polimer kompozitlerin $\mathrm{Td}_{5}, \mathrm{Td}_{10}$ ve $\mathrm{Td}_{50}$ değerleri dolgu içermeyen PHPF0 malzemesinden daha yüksektir. Buna göre, tüm kompozitlerde dolgulama sonucunda ağırlıklarının \%5'ini, \%10'unu ve \%50'sini kaybettiği sıcaklık değerlerinde sırasıyla 1,2 ila $20,3^{\circ} \mathrm{C}$, 1,0 ila $17,1^{\circ} \mathrm{C}$ ve 0,4 ila $7,9^{\circ} \mathrm{C}$ arasında değişen artışlar olmuştur. Buna göre, selüloz nanofibril dolguların polimer matris ile yaptığı kuvvetli etkileşimlerin bir sonucu olarak, polimer zincirlerinin hareketliliği kısıtlanmış [26] ve bozunma ürünlerinin ayrılmasının engellenmesiyle degradasyon sıcaklığı artmıştır [27,28]. Ağırlık kaybının en fazla olduğu pik maksimum sıcaklık değerlerinde ve bozunma hızlarında çok büyük farklılıklar olmamasına rağmen en yüksek sıcaklık değerine $\left(418,4^{\circ} \mathrm{C}\right)$ ve bozunma hızına $\left(20,39 \%\right.$.dk $\left.{ }^{-1}\right)$ PHPF 0.75 kompozitinin sahip olduğu görülmüştür. Isıl analiz sonuçlarına göre, selüloz nanofibril dolgu katkısının malzeme morfolojisinin düzelmesinin yanında daha yüksek bozunma başlangıç sıcaklıklarının elde edilmesini ve ısıl kararlılığın artmasını sağladığ 1 saptanmıştır.
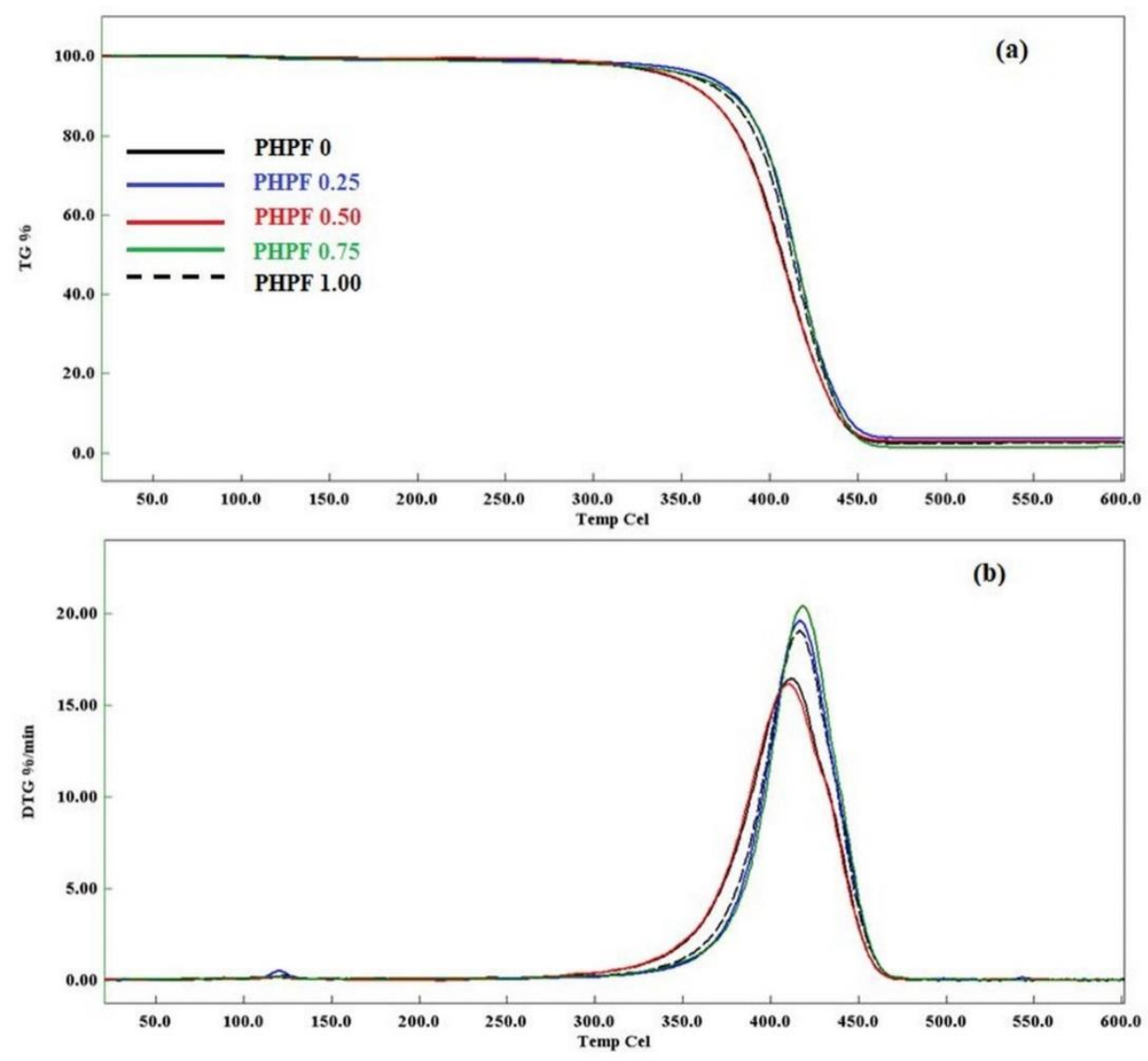

Şekil 5. Gözenekli destek malzemelerinin (a)TGA termogramları, (b) türevsel TGA termogramları 


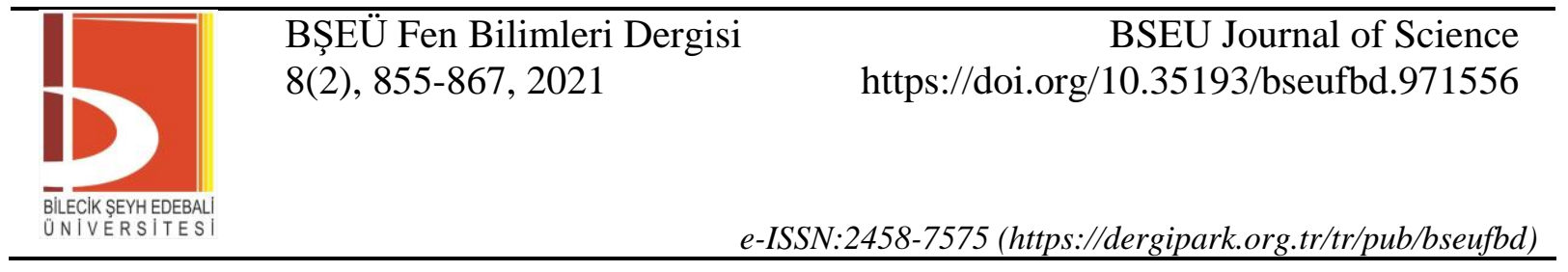

Tablo 2. Gözenekli destek malzemelerine ait termogravimetrik analiz yoluyla elde edilen isıl veriler

\begin{tabular}{lcccc}
\hline Malzeme & $\mathbf{T d}_{5}\left({ }^{\circ} \mathbf{C}\right)$ & $\mathbf{T d}_{\mathbf{1 0}}\left({ }^{\circ} \mathbf{C}\right)$ & $\mathbf{T d}_{\mathbf{5} 0}\left({ }^{\circ} \mathbf{C}\right)$ & $\begin{array}{c}\text { BozunmaHızı ve Pik } \\
\text { MaksimumSıcaklığ } \mathbf{~}\left(\mathbf{~ . d k}^{-1},{ }^{\circ} \mathbf{C}\right)\end{array}$ \\
\hline PHPF 0 & 343,1 & 364,4 & 407,1 & $16,42\left(412,2^{\circ} \mathrm{C}\right)$ \\
PHPF 0.25 & 363,4 & 381,5 & 414,5 & $19,57\left(416,9^{\circ} \mathrm{C}\right)$ \\
PHPF 0.50 & 344,3 & 365,4 & 407,5 & $16,14\left(410,1^{\circ} \mathrm{C}\right)$ \\
PHPF 0.75 & 356,4 & 379,7 & 415,0 & $20,39\left(418,4^{\circ} \mathrm{C}\right)$ \\
PHPF 1.00 & 354,9 & 376,0 & 412,9 & $19,02\left(416,2{ }^{\circ} \mathrm{C}\right)$ \\
\hline
\end{tabular}

Üretilen gözenekli destek malzemelerinin mekanik özellikleri tek eksenli basma testleri ile $10 \mathrm{kN}$ 'luk yük altında ASTM D 1621-2004 standartlarına uygun olarak test edilmiştir. Universal test cihazının orijinal yazılımından elde edilen veriler ile çizilen gerilim/gerinim grafikleri ile yine cihazın orijinal yazılımından elde edilen veriler ise sırasıyla Șekil 6 ve Tablo 3'te sunulmuștur. Tablo 3'te sunulan ve kompozit yapıllı malzemelerin basma testlerinden elde edilen mekanik test verilerinin selüloz nanofibril dolgu içermeyen polimer numunesinin verileri ile karşılaştırılması sonucunda polimer matrisin dolgu ile desteklenmesinin malzemelerin mekanik özelliklerinde nanofibril miktarı ile ilişsili olarak bir değişime neden olduğu görülmektedir. Buna ek olarak, Şekil 6'da sunulan gerilim/gerinim grafiğinin de Tablo 3 'te sunulan verilerle uyum içinde olduğu açıkça görülmektedir. Ayrıca, Şekil 6'da sunulan gerilim/gerinim grafikleri elde edilen malzemelerin tamamının yük altında aynı mekanik davranışı sergilediği de saptanmıştır. Tablo 3 'te verilen bulgulara göre en düşük yükleme oranı $(\% 0,25)$ ile hazırlanan kompozitin (PHPF 0.25) basma modülünün $\left(\mathrm{E}_{\mathrm{c}}\right)$ saf poliHIPE numunesi (PHPF 0) ile aynı olduğu belirlenmiştir. Bununla birlikte, artan yükleme miktarları ile hazırlanan kompozit malzemelerin basma modülü değerlerinde bir azalma olduğu saptanmıştır. Bu durum, elde edilen kompozit yapılı malzemeler ile dolgu içeremeyen referans polimer numunesi arasındaki temel farkın farklı oranlarda selüloz nanofibrillerin yapıyla birleştirilmesi olduğu göz önünde bulundurularak açıklanabilir. Nanofibril katkılaması dışında kullanılan öncü emülsiyonların formülasyonları (iç faz oranı, çapraz bağlayıcı oranı ve emülgatör konsantrasyonu) tamamen aynıdır. Dolayısıyla, emülsiyon şablonlama ile hazırlanan poliHIPE'lerde gözenek miktarı kullanılan iç faz hacim oranı ile ilişkili olduğundan elde edilen kompozitlerin nominal gözeneklilik değerleri, yani oluşan gözenek miktarı da aynıdır [29]. Elde edilen basma sonuçlarındaki varyasyon nanofibril katkılamasının bir sonucu olarak değerlendirilebilir. Farklı oranlardaki nanofibril kullanımı, nanofibrillerin emülsiyon içindeki homojen dağılımını etkileyebilir. Özellikle bu çalışmada olduğu gibi yüzey aktif bir madde ile modifiye edilmiş nano katkılar varlı̆̆ıında, emülsiyon fazları arasındaki yüzey geriliminin değişiminin bir sonucu olarak emülsiyon stabilitesinde de değişim olabilir ve bu durum elde edilen malzemelerin gözenek morfolojisini etkileyebilir [30]. Şekil 4(a)'dan da açıkça görülebildiği gibi nanofibril dolgu içermeyen polimer numunesinde makro gözenekler gözlemlenememektedir. Boşluk hacminin az olması sebebiyle bu numunenin en yüksek basma dayanımına sahip olması beklenen bir sonuçtur. Şekil 4 (b-d) incelendiğinde ise kompozit yapılı poliHIPE'lerden nanofibril katkısı arttıkça gözenek morfolojisinin düzeldiği görülmektedir. Bu sonuç ise nanofibril miktarı arttıkça, modifiye edilmiş nanofibrillerden gelen yüzey aktif madde katkısının da artması ile açıklanabilir. Sonuç olarak, $\% 0.25$ oranında nanofibril ilavesi gözenek morfolojisininde, mekanik dayanımı önemli düzeyde etkileyecek bir değişime sebep olmamıştır. Ancak, nanofibril miktarı \%0,50'ye çıkarıldığında oluşan makro gözeneklerin miktarı, boyutu ve boyut dağılımı artmıştır. Bu durum basma dayanımında \%26,36'llk bir azalmaya sebep olmuştur. Şekil 4 ve Tablo 3 birlikte değerlendirildiğinde ise katkılama oranı $\% 0,75$ ve $\% 1,0$ olduğunda hem gözenek boyutları ve boyut dağılımı azalmış hem de basma dayanımı değerleri tekrar artmıştır. Elbette ki bu artışta kullanılan yüksek orandaki nanofibril miktarının gözenek duvarlarında oluşturduğu desteğin etkisi de mevcuttur. Tüm bunlara ek olarak, artan yüzey aktif madde miktarının elde edilen kompozit malzemelerde plastikleştirici etki gösterme olasılı̆̆ da göz önünde bulundurulmalıdır [31]. Nanofibrillerin yüksek oranda mekanik destekleyici görevi görmesine rağmen $\% 1,0$ oranında nanofibril içeren kompozit malzemenin referans numuneye kıyasla daha düşük basma dayanımı göstermesi bu duruma da atfedilebilir. 


\begin{tabular}{|c|c|c|}
\hline & $\begin{array}{l}\text { BŞEÜ Fen Bilimleri Dergisi } \\
8(2), 855-867,2021\end{array}$ & $\begin{array}{r}\text { BSEU Journal of Science } \\
\text { https://doi.org/10.35193/bseufbd.971556 }\end{array}$ \\
\hline & & 2458-7575 (https://dergipark.org.tr/tr/pub/bseufbd) \\
\hline
\end{tabular}

Basma gerilimi bir malzemenin belirli bir rölatif deformasyon değerine ulaşmadan ne kadar yüke dayanabileceğinin bir göstergesidir. Tablo 3'de sunulan \%10 bağıl deformasyonda basınç gerilimi değerleri $\left(\sigma_{10}\right)$ ise malzemelerin rölatif deformasyon \%10'a ulaştığ malzeme \%10 deformasyona ulaştığında kırılır ve tersinmez deformasyona uğrar ise kaydedilen $\sigma_{10}$ değerleri aynı zamanda malzemenin basma dayanımına $\left(\sigma_{c}\right)$ eşit olur. Buna göre, Tablo 3'te verilen $\sigma_{10}$ değerleri $\% 10$ deformasyona ulaşıldığı anda poliHIPE’lerin karşı koyabileceği yük miktarını göstermektedir. Bununla birlikte, Şekil 6'dan hazırlanan poliHIPE'lerin tamamında deformasyon \%10'a eşit olduğu anda (\%10 gerilim değerinde) kırılma olayının gerçekleşmediği görülebilir. Dahası, ASTM D 1621-2004 standardına göre gerçekleştirilen basma testleri \%13 deformasyon değerine ulaşıldığında sonlandırıldığından, uygulanan test şartlarında hiçbir poliHIPE malzemesinin kırılmaya uğramadığı da açıkça görülmektedir. Tüm bunlara ek olarak, düşük yükleme miktarları ile hazırlanan poliHIPE kompozitlerinin $\sigma_{10}$ değerlerinin selüloz nanofibril içermeyen saf poliHIPE numunesi ile benzer olduğu gözlemlenmiştir ve yüksek yükleme miktarlarında $\sigma_{10}$ değerlerinin saf poliHIPE numunesine kıyasla ihmal edilebilecek düzeyde azaldığı tespit edilmiştir (Tablo 3).

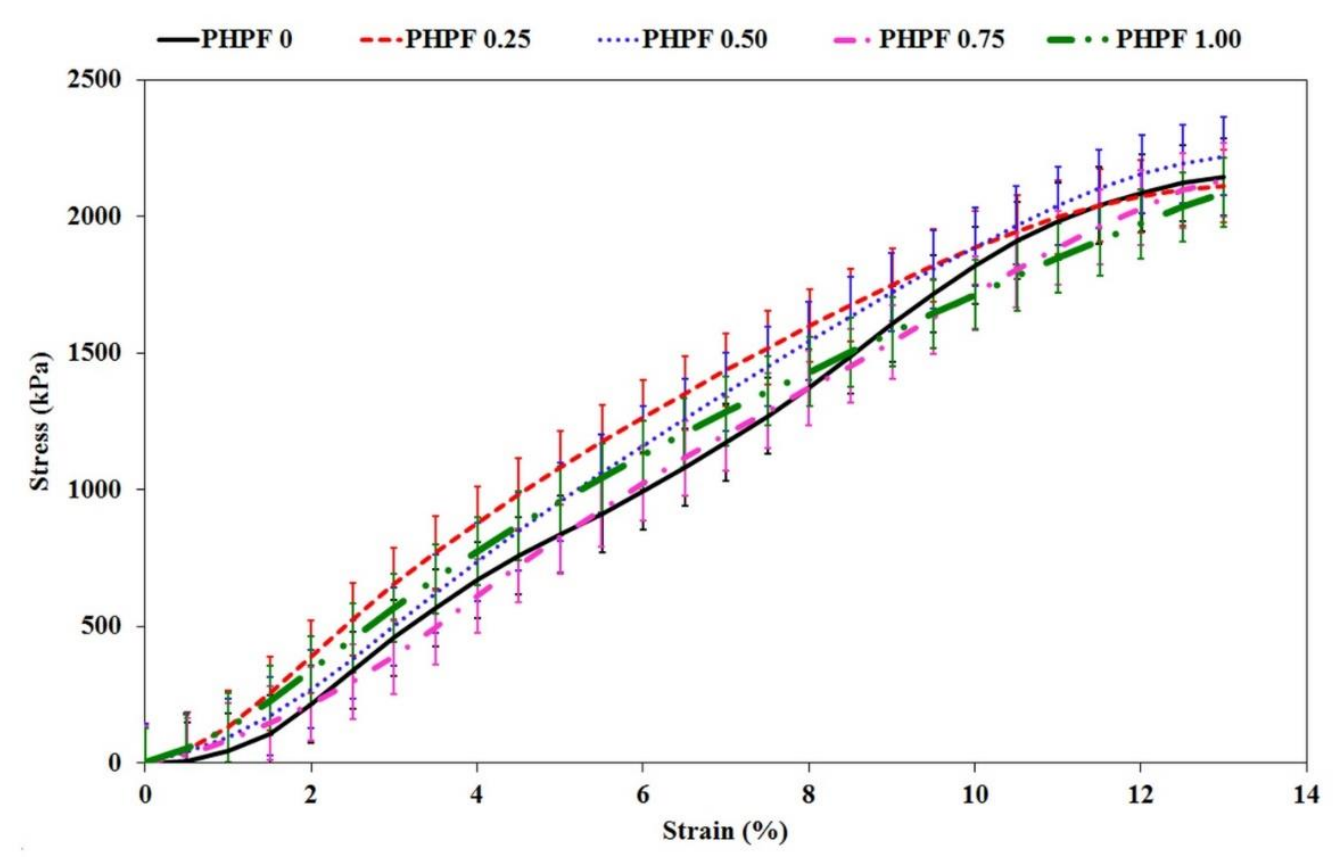

Şekil 6. Gözenekli destek malzemelerinin basma modülü grafikleri

Tablo 3. Gözenekli destek malzemelerine ait basma modülü ölçüm değerleri

\begin{tabular}{lcc}
\hline Malzeme & $\mathbf{E}_{\mathbf{c}}(\mathbf{M P a})$ & $\boldsymbol{\sigma}_{\mathbf{1 0}}(\mathbf{M P a})$ \\
\hline PHPF 0 & 25,40 & 1,95 \\
PHPF 0.25 & 25,40 & 1,98 \\
PHPF 0.50 & 20,10 & 1,98 \\
PHPF 0.75 & 21,90 & 1,82 \\
PHPF 1.00 & 22,70 & 1,79 \\
$\mathbf{E}_{\mathbf{c}}:$ Basma Modülü & \\
$\boldsymbol{\sigma}_{10}: \% 10$ bağ 1 deformasyonda basınç gerilimi & \\
\hline
\end{tabular}


Selüloz nanofibril katkılı gözenekli kompozit materyaller, soğutma uygulamalarında kullanılabilecek düşük faz geçiş sıcaklığına sahip bir parafin olan n-pentadekanı içeren yapıca kararlı FDM üretimi için destek materyali olarak kullanılmıștır. Gerçekleştirilen impregnasyon işlemi sonucunda elde edilen kompozit FDM'lerin gizli ısı depolama kapasitelerinin belirlenmesi amacıyla DSC analizi yapılmış ve elde edilen ısıl eğriler Şekil 7'de, bunlara ait veriler ise Tablo 4'te karşılaştırmalı olarak sunulmuştur. Isıtma ve soğutma periyodları sonucu elde edilen veriler incelendiğinde n-pentadekanın erime ve kristallenme pik sıcaklıkları sırasıyla $15,21{ }^{\circ} \mathrm{C}$ ve $3,1{ }^{\circ} \mathrm{C}$ bulunurken, erime ve kristallenme entalpileri ise sirasiyla $199,60 \mathrm{~J} / \mathrm{g}$ ve $-209,1 \mathrm{~J} / \mathrm{g}$ olarak tespit edilmiştir. Hazırlanan FDM kompozitlerin saf n-pentadekana kıyasla erime sıcaklıkları ve kristallenme pik sıcaklıklarında anlamlı bir değişim olmamıştır. Üretilen kompozitlerin Denklem (1)'e göre hesaplanan n-pentadekan içeriği \%12,09 ila \%61,12 arasında değişiklik göstermiş, en yüksek ısıl enerji depolama kapasitesine PHPF 0.75PD kompozitinin sahip olduğu görülmüștür. Bu malzemenin pik erime ve kristallenme sıcaklıkları sırasıyla $11,87{ }^{\circ} \mathrm{C}$ ve $5,36{ }^{\circ} \mathrm{C}$ olarak tespit edilmiş, erime ve kristallenme entalpileri ise sırasıyla $122,0 \mathrm{~J} / \mathrm{g}$ ve $-125,8 \mathrm{~J} / \mathrm{g}$ olarak ölçülmüştür. Morfolojisi ve ısıl kararlılığ selüloz nanofibril dolguların katkılandırılmasıyla iyileştirilmiş̧ bir destek matrisine sahip PHPF 0.75-PD kompozit FDMnin, sahip olduğu yüksek ısıl enerji depolama kapasitesi ve düşük sıcaklıklı uygulamalar için uygun faz geçiş sıcaklık değerleriyle soğutma sistemlerinde kullanılma potansiyeli mevcuttur.
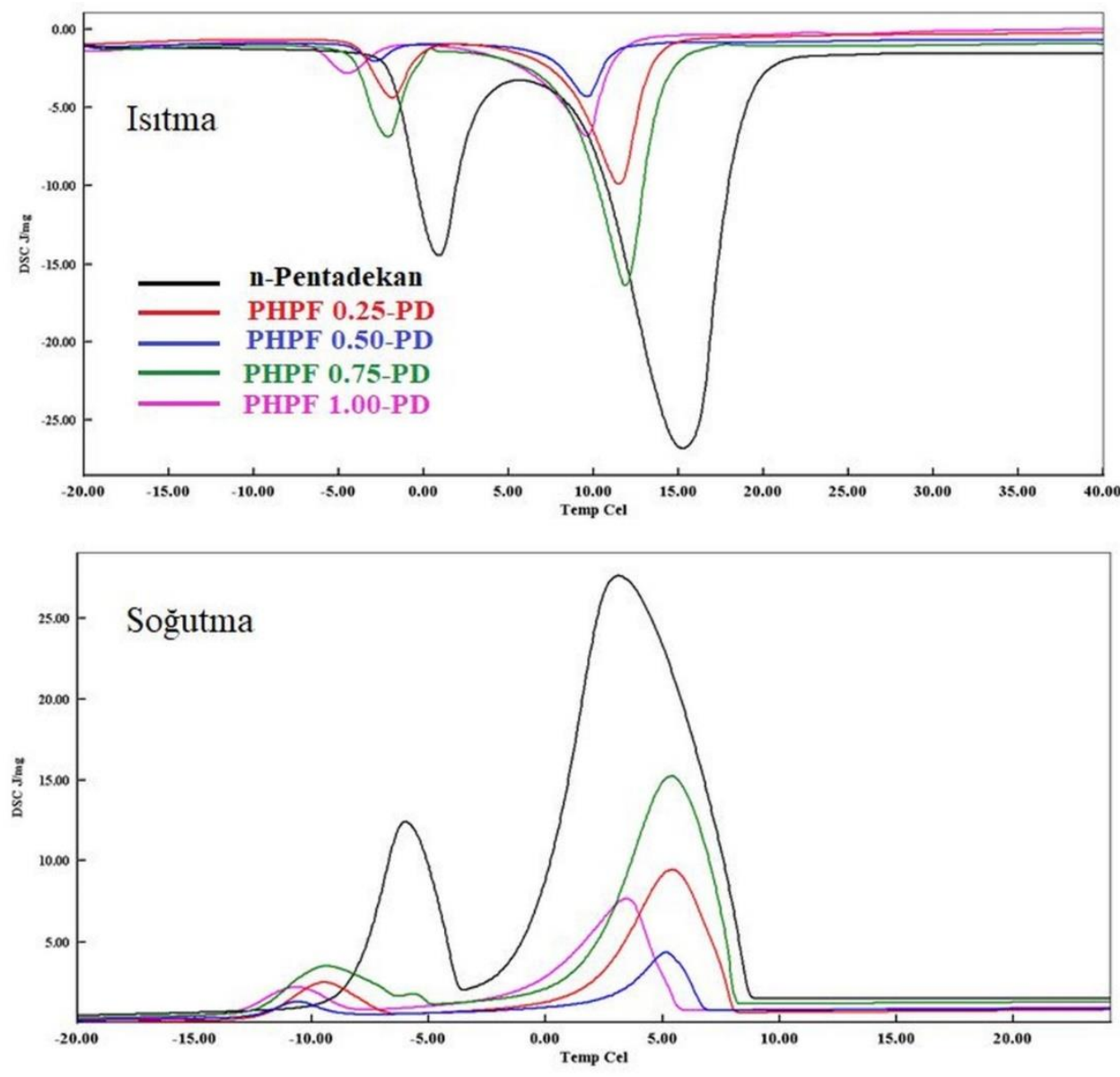

Şekil 7. N-pentadekan ve kompozit FDM'lerin DSC analizinden elde edilen 1sıl eğriler 


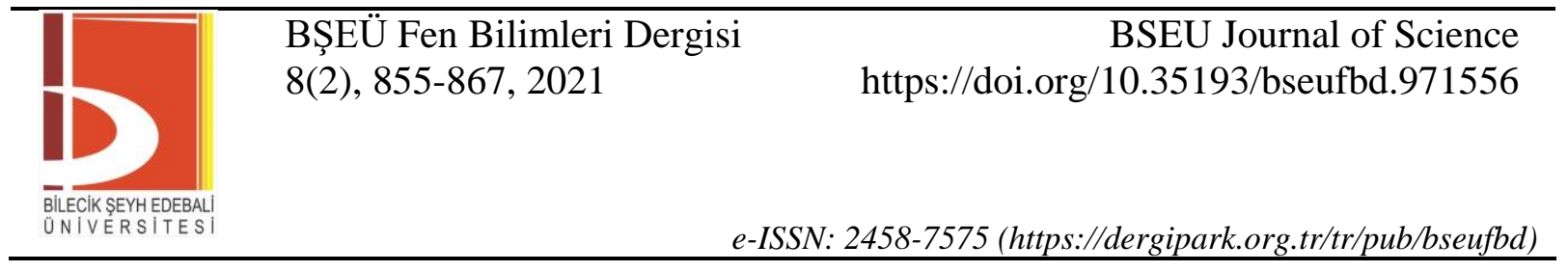

Tablo 4. N-pentadekan ve kompozit FDM'lerin DSC analizinden elde edilen 1sıl veriler

\begin{tabular}{|c|c|c|c|c|c|c|c|}
\hline \multirow[b]{2}{*}{ Malzeme } & \multicolumn{3}{|c|}{ Isitma periyodu } & \multicolumn{3}{|c|}{ Soğuma periyodu } & \multirow[b]{2}{*}{$\begin{array}{c}\text { N-pentadekan } \\
\text { içeriği } \\
\text { (\% ağırlıkça) }\end{array}$} \\
\hline & $\begin{array}{c}\text { Katı-katı } \\
\text { geçişi } \\
\text { pik sıcaklığı } \\
\left({ }^{\circ} \mathbf{C}\right)\end{array}$ & $\begin{array}{c}\text { Katı-sıvı } \\
\text { erime } \\
\text { pik sıcaklığı } \\
\left({ }^{\circ} \mathrm{C}\right)\end{array}$ & $\begin{array}{c}\text { Toplam } \\
\text { gizli isı } \\
\Delta \mathbf{H} \\
(\mathrm{J} / \mathrm{g}) \\
\end{array}$ & $\begin{array}{c}\text { Sıvı-katı } \\
\text { kristallenme } \\
\text { pik sıcaklığı } \\
\left({ }^{\circ} \mathrm{C}\right)\end{array}$ & $\begin{array}{c}\text { Katı-katı } \\
\text { geçişi } \\
\text { pik sıcaklığı } \\
\left({ }^{\circ} \mathrm{C}\right) \\
\end{array}$ & $\begin{array}{c}\text { Toplam } \\
\text { gizli isı } \\
\Delta \mathbf{H} \\
(\mathbf{J} / \mathbf{g}) \\
\end{array}$ & \\
\hline N-pentadekan & 0,90 & 15,21 & 199,60 & 3,11 & $-5,99$ & $-209,1$ & 100 \\
\hline PHPF 0.25-PD & $-1,86$ & 11,48 & 85,40 & 5,43 & $-9,46$ & $-89,0$ & 42,79 \\
\hline PHPF 0.50-PD & $-2,87$ & 9,59 & 24,14 & 5,14 & $-10,62$ & $-28,57$ & 12,09 \\
\hline PHPF 0.75-PD & $-2,10$ & 11,87 & 122,00 & 5,36 & $-9,36$ & $-125,8$ & 61,12 \\
\hline PHPF 1.00-PD & $-4,45$ & 9,64 & 53,30 & 3,46 & $-10,66$ & $-61,7$ & 26,70 \\
\hline
\end{tabular}

\section{SONUCLAR}

Bu çalışmada, biyokütle kökenli ve sürdürülebilir bir hammadde olan selüloz nanofibriller içeren gözenekli polimer kompozitler, yüksek iç fazlı emülsiyonların kalıplanması yoluyla hazırlanmıştır. Üretilen emülsiyon şablonlu gözenekli yapılar, organik FDM sınıfında yer alan ve $\mathrm{C}_{15} \mathrm{H}_{32}$ kimyasal formülüne sahip bir hidrokarbon olan n-pentadekanın kapsüllenmesinde destek malzemesi olarak kullanılmıştır. Elde edilen kompozit malzemelerin morfolojisinde dolgu artışılla iyileşme görülmüş, en yüksek spesifik yüzey alanı değerine en yüksek dolgulama oranında ulaşılmıştır. Diğer yandan polimer matrisin dolgu ile desteklenmesinin malzemelerin mekanik özelliklerinde önemli bir değişime neden olmadığı saptanmıştır. Malzemelerin gerçekleştirilen isıl karakterizasyonları sonucunda selüloz nanofibril dolguların malzemelerin 1sıl kararlılıklarına olumlu katkı sağladığı ve bozunma başlangıç sıcaklıklarını daha yüksek sıcaklık değerlerine ötelediği tespit edilmiştir. Hazırlanan polimer kompozitlerin, yapıca kararlı ssıl enerji depolama malzemelerinin hazırlanmasında yapısal iskelet olarak kullanılmasıyla üretilen n-pentadekan içerikli enerji malzemelerinin erime gizli ısı değerlerinin 24,14-122,0 J/g arasında değişiklik gösterdiği belirlenmiştir. En yüksek n-pentadekan içeriğine \%61,12 değeriyle PHPF 0.75-PD kompozit faz değiştiren maddesinin sahip olduğu, uygun erime ve kristallenme pik sıcaklıkları ve yüksek enerji depolama kapasitesiyle $(122,0 \mathrm{~J} / \mathrm{g})$ düşük sıcaklıklı $1 \mathrm{~s} 1$ enerji depolama uygulamalarında kullanılabilecek bir referans malzeme olabileceği öngörülmüştür.

\section{TEŞEKKÜR}

Bu çalışmanın gerçekleştirilmesinde proje desteği sağlayan Yalova Üniversitesi Bilimsel Araştırma Projeleri Koordinasyon Birimi’ne (Proje Numarası: 2020/YL/0005) teşekkür ederiz.

\section{KAYNAKLAR}

[1] Mert, M. S., Sert, M., \& Mert, H. H. (2018). Isıl Enerji Depolama Sistemleri İçin Organik Faz Değiştiren Maddelerin Mevcut Durumu Üzerine Bir İnceleme. Mühendislik Bilimleri ve Tasartm Dergisi, 6(1)161-174.

[2] Teggar, M., Arıcı, M., Mert, M. S., Ajarostaghi, S. S. M., Niyas, H., Tunçbilek, E., Ismail, K. A. R., Younsi, Z., Benhouia, A. T., \& Mezaache, E. H. (2021). A comprehensive review of micro / nano enhanced phase change materials. Journal of Thermal Analysis and Calorimetry, https://doi.org/10.1007/s10973-021-108080 .

[3] Zhang, Y., Tang, B., Wang, L., Lu, R., Zhao, D., \& Zhang, S. (2017). Novel hybrid form-stable polyether phase change materials with good fire resistance. Energy Storage Materials, 6, 46-52.

[4] Mert, M. S., Mert, H. H., \& Sert, M. (2019). Microencapsulated oleic-capric acid/hexadecane mixture as phase change material for thermal energy storage. Journal of Thermal Analysis and Calorimetry, 136, 15511561.

[5] Mert, H. H., \& Mert, M. S. (2021). Design of n-Octadecane-Based Form-Stable Composite Phase Change Materials Embedded In Porous Nano Alumina For Thermal Energy Storage Applications. Journal of Thermal Analysis and Calorimetry, https://doi.org/10.1007/s10973-021-10886-0.

[6] Huang, X., Chen, X., Li, A., Atinafu, D., Gao, H., Dong, W., \& Wang, G. (2019). Shape-Stabilized Phase Change Materials Based on Porous Supports for Thermal Energy Storage Applications. Chemical Engineering Journal, 356, 641-661.

[7] Fang, G., Li, H., Chen, Z., \& Liu, X. (2010). Preparation and Characterization of Flame Retardent nHexadecane / Silicon dioxide Composites as Thermal Energy Storage Materials. Journal of Hazardous Materials, 181, 1004-1009. 
[8] Jeon, J., Jeong S. G., Lee, J. H., Seo, J., \& Kim, S. (2012). High Thermal Performance Composite PCMs loading xGnP for Application to Building Using Radiant Floor Heating System. Solar Energy Materials \& Solar Cells, 101, 51-56.

[9] Umair, M. M., Zhang, Y., Iqbal, K., Zhang, S., \& Tang, B. (2019). Novel Strategies and Supporting Materials Applied to Shape-stabilize Organic Phase Change Materials for Thermal Energy Storage-A Review. Applied Energy, 235, 846-873.

[10] Mert, E. H., \& Mert, H. H. (2021). Preparation of polyHIPE nano composites: Revealing the influence of experimental parameters with the help of experimental design approach. Polymer Composites, 42, 724-738.

[11] Puupponen, S., Mikkola, V., Ala-Nissila, T., \& Seppala, A. (2016). Novel Microstructured PolyolPolystyrene Composites for Seasonal Heat Storage. Applied Energy, 172, 96-106.

[12] Balderramaa, J. A. M., Dourgesa, M-A., Magueresseb, A., Maheob, L., Deleuzea, H., \& Glouannecc, P. (2018). Emulsion-Templated Pullulan Monoliths as Phase Change Materials Encapsulating Matrices. Materials Today Communications, 17, 466-473.

[13] Mert, H. H. (2020). PolyHIPE Composite Based-Form Stable Phase Change Material for Thermal Energy Storage. International Journal of Energy Research, 44, 6583-6594.

[14] Döğüşcü, D. K., Hekimoğlu, G., \& Sarı, A. (2021). High Internal Phase Emulsion Templated-Polystyrene / Carbon Nano Fiber / Hexadecanol Composites Phase Change Materials for Thermal Management Applications. Journal of Energy Storage, 39, 102674.

[15] Yüce E., Krajnc P., Mert, H. H., \& Mert, E. H. (2019). Influence of Nanoparticles and Antioxidants on Mechanical Properties of Titania / Polydicyclopentadiene PolyHIPEs: A Statistical Approach. Journal of Applied Polymer Science, 136 (7) 46913.

[16] Abbasian, Z., \& Moghbeli, M. R. (2011). Preparation of Highly Open Porous Styrene/Acrylonitrile and Styrene / Acrylonitrile / Organoclay Polymerized High Internal Phase Emulsion (PolyHIPE) Foams via Emulsion Templating. Journal of Applied Polymer Science, 119, 3728.

[17] Lavoine, N., \& Bergström, L. L. (2017). Nanocellulose based Foams and Aerogels: Processing, Properties, and Applications. Journal of Materials Chemistry A, 5, 16105-16117.

[18] Antonini, C., Wu, T., Zimmermann, T., Kherbeche, A., Thoraval, M., Nyström, G., \& Geiger, T. (2019). Ultra-Porous Nanocellulose Foams A Facile and Scalable Fabrication Approach. Nanomaterials, 9, 1142.

[19] Abitbol, T, Marway, H., \& Cranston, E. D. (2014). Surface Modification of Cellulose Nanocrystals with Cetyltrimethylammonium Bromide. Nanocellulose Nordic Pulp \& Paper Research Journal, 29 (1), 46-57.

[20] Salajkova, M., Berglund L. A., \& Zhou, Q., (2012). Hydrophobic cellulose nanocrystals modified with quaternary ammonium Salts. Journal of Materials Chemistry, 22, 19798-19805.

[21] Li, Y., Yu, S., Chen, P., Rojas, R., Hajian, A., \& Berglund, L. (2017).Cellulose Nanofibers Enable Paraffin Encapsulation and the Formation of Stable Thermal Regulation Nanocomposites. Nano Energy, 34, 541-548.

[22] Zhang, Z., Zhang, Z., Chang, T., Wang, J., Wang, X., \& Zhou, G. (2021). Phase Change Material Microcapsules with Melamine Resin Shell via Cellulose Nanocrystal Stabilized Pickering Emulsion In-Situ Polymerization. Chemical Engineering Journal, 131164, https://doi.org/10.1016/j.cej.2021.131164.

[23] Shen, Z., Oh, k., Kwon, S., Toivakka, M., \& Hak L. L. (2021). Use of cellulose nanofibril (CNF)/silver nanoparticles (AgNPs) composite in salt hydrate phase change material for efficient thermal energy storage. International Journal of Biological Macromolecules, 174, 402-412.

[24] Kanlı, Z., Mert, M. S., \& Mert, H. H. (2021). Isıl Enerji Depolama Uygulamaları İçin Selüloz Nanofibril Temelli Parafin İçeren Kompozit Faz Değiştiren Maddelerin Üretilmesi ve Karakterizasyonu. Avrupa Bilim ve Teknoloji Dergisi, (22), 273-281.

[25] Reddy, K. O., Maheswari, C. U., Dhlamini, M. S., \& Kommula V. P. (2016). Exploration on the Characteristics of Cellulose Microfibers from Palmyra Palm Fruits. International Journal of Polymer Analysis and Characterization, 21(4), 286-295.

[26] Mert, H. H., \& Şen, S. (2016). Synthesis and Characterization of PolyHIPE Composites Containing Halloysite Nanotubes. E-Polymers, 16(6), 419-428.

[27] Aydınoğlu, D., Akgül, Ö., Bayram, V., \& Şen, S. (2014). Polymer Nanocomposites Hydrogels with Improved Metal Adsorption Capacity and Swelling Behaviour: Influence of Spirulina Immobilization onto Montmorillonite Clay. Polymer-Plastics Technology and Engineering, 53, 1706-1722.

[28] Mert, H. H., \& Mert, M. S. (2019). Preparation and Characterization of Encapsulated Phase Change Materials in Presence of Gamma Alumina for Thermal Energy Storage Applications. Thermochimica Acta, 681, 178382. 
[29] Mert, H. H., Mert, M. S., \& Mert, E. H. (2019). A Statistical Approach for Tailoring the Morphological and Mechanical Properties of Polystyrene PolyHIPEs: Looking Through Experimental Design. Materials Research Express, 6, 115306.

[30] Berber, E., Çira, F., \& Mert, E. H. (2016). Preparation of Porous Polyester Composites via Emulsion Templating: Investigation of the Morphological, Mechanical, and Thermal Properties. Polymer Composites 37(5) 1531-1538.

[31] Wu, R., Menner, A., \& Bismarck, A. (2013). Macroporous Polymers Made From Medium Internal Phase Emulsion Templates: Effect of Emulsion Formulation on the Pore Structure of PolyMIPEs. Polymer 54(21) 5511-5517. 